\title{
Peran Serta Subak Dalam Program Penangkaran Benih Padi PT. Pertani (Persero) \\ (Kasus Di Subak Bengkel, Desa Bengkel, Kecamatan Kediri, Kabupaten Tabanan)
}

\author{
MADE DHARMA HADIKUSUMA, I DEWA PUTU OKA SUARDI, \\ NI WAYAN SRI ASTITI \\ Program Studi Agribisnis, Fakultas Pertanian, Universitas Udayana \\ Jl. PB. Sudirman Denpasar 80323 \\ E-mail : dharmahadi87@gmail.com \\ okasuardi@unud.ac.id
}

\begin{abstract}
Participation Of Irrigation Organization Of Subak In The Program Of Rice Seed Breeding Of Pt. Pertani (Persero)

(A Case In The Subak Bengkel, Bengkel Village, Kediri Sub-District Of Tabanan Regency)
\end{abstract}

PT. Pertani is a state-owned company engaged in seeding. In SubakBengkel, the participating parties in the breeding program were only TempekPagedangan. The purpose of this research is to investigate the role of farmers, the benefits and constraints in seed breeding program. The approach used is qualitative descriptive method. The results of the research show that participation in social aspect covers the activity of farmer giving idea, opinion and thought. Participation in terms of economic aspects include payment of contributions and voluntary contributions. Participation in terms of technical aspects include farmer breeders want to adopt rice seeding techniques. The benefits of breeding programs from the social aspect include good relationships among fellow breeders, good relationships with partners. Benefits in terms of economic aspects include higher purchased of grain prices. Benefits in terms of technical aspects of obtaining rice cultivation techniques. Constraints in the breeding program from the social aspect include: strict requirements of PT. Pertani, it is difficult to change perceptions and there is a threat from rice milling. Constraints in terms of economic aspects include a lack of money and land capital. Obstacles in terms of technical aspects include lazy farmers and hard to get the basic seed. Based on the results of the research, it can be concluded that the farmers were greatly participating in the SubakBengkel in breeding program. Judging from the problem, farmers are expected to learn the cultivation of rice seed, PT. Pertani should disseminate the program intensively, the community group of TempekPagedangan should immediately solve the problem by consensus.

Keywords: participation, subak, PT. Pertani (Persero), breeding of rice seed. 


\section{Pendahuluan \\ 1.1 Latar Belakang}

Indonesia sebagai negara dengan jumlah penduduk yang besar menghadapi tantangan yang sangat kompleks dalam memenuhi kebutuhan pangan penduduknya. Hal ini disebabkan karena meningkatnya jumlah penduduk yang berbanding lurus dengan peningkatan kebutuhan pangan karena pada dasarnya pangan merupakan kebutuhan pokok bagi masyarakat. Memenuhi kebutuhan pangan masyarakat, pemerintah Indonesia sebagai negara yang berdaulat berkomitmen mewujudkan ketahanan pangan hal ini tertuang dalam Undang-Undang No.7 tahun 1996 tentang pangan, dan ditindaklanjuti dengan peraturan pemerintah Republik Indonesia No.28 Th 2002 tentang ketahanan pangan yang mengamanatkan bahwa pemerintah bersama masyarakat bertanggungjawab untuk mewujudkan ketahanan pangan bagi seluruh rakyat (Suryana, 2003). Ketahanan pangan dapat diartikan sebagai kondisi terpenuhinya pangan bagi rumah tangga yang tercermin dari tersediaannya pangan yang cukup, baik jumlah maupun mutunya, aman, merata dan terjangkau (Ariani, 2007). Salah satu komoditas pertanian yang diusahakan dalam pemenuhan kebutuhan pangan adalah padi. Padi merupakan tanaman pangan yang penting bagi mayoritas masyarakat Indonesia yang sangat dibutuhkan dalam kesehariannya sebagai makanan pokok. Ketersediaan benih unggul bermutu tinggi bagi petani dalam kegiatan usahatani adalah syarat penting dalam peningkatan hasil dan kualitas produksi (Hanafi, 1998). Salah satu perusahaan yang melakukan penyediaan benih unggul adalah PT. Pertani (Persero).

PT. Pertani (Persero) merupakan salah satu perusahaan BUMN yang bergerak dalam bidang pembenihan dan perberasan. PT. Pertani (Persero) memiliki program penangkaran benih padi dimana bekerjasama dengan petani dalam menyediakan bahan benih padi. Subak Bengkel merupakan salah satu subak yang ada di Desa Bengkel, Kecamatan Kediri, Kabupaten Tabanan. Subak Bengkel memiliki empat tempek yakni Tempek Babakan, Tempek Pagedangan, Tempek Celacar, dan Tempek Pagedangan Kauh, yang ikut berperan serta dalam program penangkaran benih padi dengan PT. Pertani (Persero) hanya Tempek Pagedangan.

Peran serta Tempek Pagedangan dan subak/kelompok tani lainnya dalam mengikuti program penangkaran benih padi didasarkan atas surat perjanjian berbadan hukum (MOU). Empat tempek tersebut yang ikut berperan serta dalam program penangkaran benih padi dengan PT Pertani (Persero) hanya Tempek Pagedangan, padahal banyak manfaat yang bisa didapat jika ikut dalam program penangkaran benih dari PT. Pertani (Persero). Semakin tinggi permintaan pasar akan benih maka PT Pertani (Persero) membutuhkan lebih banyak lagi peran serta dari subak atau tempek untuk memenuhi kebutuhan benih padi dalam rangka pengadaan benih padi dari program pemerintah dan kebutuhan konsumen pasar. Belum berpartisipasinya ketiga tempek yang ada di Subak Bengkel terindikasinya adanya kendala-kendala dalam mengikuti program penangkaran benih padi.

\subsection{Rumusan Masalah}

Berdasarkan dari latar belakang dapat ditarik beberapa rumusan masalah yaitu:

1. Bagaimana peran serta subak dalam program penangkaran benih padi dilihat dari aspek sosial, aspek ekonomi, dan aspek teknis. 
2. Manfaat apa yang diperoleh subak dilihat dari aspek sosial, aspek ekonomi, dan aspek teknis.

3. Kendala-kendala yang dihadapi oleh Subak Bengkel dalam mengikuti program penangkaran benih padi ditinjau dari aspek sosial, aspek ekonomi, dan aspek teknis

\subsection{Tujuan Penelitian}

Dengan memperhatikan masalah yang telah dikemukakan di atas, maka tujuan penelitian ini adalah untuk mengetahui peran serta Subak Bengkel dalam mengikuti program penangkaran benih padi dilihat dari aspek sosial, aspek ekonomi dan aspek teknis, yang kedua untuk mengetahui manfaat yang diperoleh dalam mengikuti program penangkaran benih padi dilihat dari aspek sosial, aspek ekonomi dan aspek teknis, dan yang terakhir untuk mengetahui kendala-kendala yang dihadapi Subak Bengkel dalam mengikuti program penangkaran benih padi ditinjau dari aspek sosial, aspek ekonomi dan aspek teknis.

\section{Metode Penelitian}

\subsection{Lokasi dan Waktu Penelitian}

Lokasi penelitian dilakukan di Tempek Pagedangan Subak Bengkel, Desa Bengkel, Kecamatan Kediri, Kabupaten Tabanan. Pemilihan lokasi ini dilakukan secara sengaja (purposive), waktu pengumpulan data primer dan data skunder berlangsung dari bulan Juli - September 2017 mulai dari persiapan hingga penyusunan skripsi. Adapun pertimbangan pemilihan lokasi penelitian ini sebagai berikut.

1. Salah satu tempek Subak Bengkel yaitu Tempek Pagedangan merupakan penangkar benih dari PT Pertani (Persero) yang sudah berperan serta selama 17 tahun dalam program penangkaran benih padi.

2. Salah satu penangkar benih padi dengan produksi calon benih terbesar di Bali.

3. Subak Bengkel merupakan salah satu subak yang masih eksis dibidang pertanian.

\subsection{Sumber dan Jenis Data}

Sumber data dalam penelitian ini meliputi data primer dan data sekunder. Data primer dalam penelitian ini yaitu data primer digali melalui wawancara mendalam dengan informan kunci. Data primer adalah data yang langsung dikumpulkan oleh orang yang berkepentingan atau yang menggunakan data tersebut (Ibrahim, 2015). Data sekunder dalam penelitian ini yakni dokumen atau arsip (baik dari desa dan subak). Data sekunder pada umumnya digunakan untuk memberikan gambaran tambahan, gambaran pelengkap atau diproses lebih lanjut (Ibrahim, 2015). Jenis data terdiri data kualitatif dan kuantitatif. Data kualitatif yaitu data yang berbentuk kata-kata atau yang berwujud pernyataan-pernyataan verbal, bukan dalam bentuk angka atau menguraikan paradigma fenomena yang ada di lapangan secara alamiah dengan kata-kata atau gambar (Antara, 2006). Data kualitatif adalah data yang berwujud uraian terinci, kutipan langsung, dan dokumentasi kasus. Data ini dikumpulkan secara cerita terbuka (openended narrative), tanpa mencoba mencocokkan suatu gejala dengan kategori baku yang telah ditetapkan sebelumnya, sebagaimana jawaban pertanyaan dalam kuesioner (Sitorus, 1998 dalam Agusta, 2012). Data kuantitatif, yaitu data yang berupa angkaangka dan dapat dihitung dalam satuan tertentu. Data kuantitatif yang diperoleh dan 
dikumpulkan dalam penelitian ini dipisahkan menurut jenisnya. Selanjutnya diolah, dianalisis dan dijadikan dalam bentuk tabel-tabel frekuensi dan diberi penjelasan berdasarkan hasil kuesioner dari responden (Antara, 2006).

\subsection{Informan Kunci}

Peneliti menentukan informan kunci dengan teknik purposive sampling, Pemilihan sempel seperti dilakukan karena peneliti telah memahami bahwa informasi yang dibutuhkan dapat diperoleh dari suatu kelompok sasaran tertentu yang mampu memberikan informasi yang dikehendaki (Sugiyono, 2009).

Berikut beberapa informan kunci penelitian yang sudah dipilih yaitu : a). Ketua Tempek Pagedangan, b). Sekretaris 1 Tempek Pagedangan, c). Sekretaris 2 Tempek Pagedangan, d). Bendahara 1 Tempek Pagedangan, e). Bendahara 2 Tempek Pagedangan, f). Ketua Tempek Celacar, g). Ketua Tempek Babakan, h). Ketua Tempek Pagedangan Kauh.

\subsection{Pengumpulan Data}

Metode pengumpulan data dalam penelitian ini melalui wawancara mendalam observasi dan dokumentasi. Wawancara mendalam (Indepht interview) dilakukan dengan informan kunci yang berjumlah 8 orang yang telah ditentukan menggunakan instrument penelitian, indepth interview merupakan sebuah wawancara untuk menggali informasi secara mendalam, terbuka, dan bebas dengan masalah dan fokus penelitian sesuai dengan pedoman wawancara yang telah disediakan sebelumnya Moleong, 2005 (dalam Wahyuni, 2014). Indepth interview merupakan proses memperoleh keterangan untuk tujuan penelitian dengan cara tanya jawab dan bertatap muka, dimana informasi terlibat dalam kehidupan sosial yang relatif lama (Sutopo, 2006). Observasi merupakan pengamatan secara langsung pada objek penelitian yakni pengamatan langsung pada daerah penelitian agar memperoleh gambaran keadaan yang sesungguhnya dari objek penelitian, dan dokumentasi merupakan catatan peristiwa yang sudah berlalu. Dokumen bisa berbentuk tulisan, gambar, atau karya-karya monumental dari seseorang. Dokumen yang berbentuk tulisan misalnya catatan harian, sejarah kehidupan, peraturan maupun kebijakan. Dokumen yang berupa gambar yaitu dalam bentuk foto serta bentuk yang lainnya (Sugiyono, 2009).

\subsection{Analisis Data}

Analisis data menggunakan analisis deskriptif kualitatif yang diperoleh dari hasil observasi, wawancara mendalam, dan dokumentasi. Analisis data digunakan dengan tiga langkah yaitu : pengumpulan data, klasifikasi data, interpretasi data, dan penarikan kesimpulan akhir (Ibrahim, 2015).

1. Mengumpulkan data sebanyak mungkin dilapangan.

2. Data-data yang telah dikumpulkan diklarifikasi sesuai dengan aspek kajian yang telah ditentukan dalam penelitian ini.

3. Data-data yang sudah diklarifikasi dalam aspek penelitian kemudian ditafsirkan dan dimaknai sebagai sebuah kesimpulan akhir dari penelitian ini. 


\section{Gambaran Umum Lokasi Penelitian \\ 3.1 Deskripsi Subak Bengkel}

Subak Bengkel merupakan subak yang ada di Desa Bengkel Kecamatan Kediri Kabupaten Tabanan. Subak Bengkel meliputi dua desa dinas yaitu Desa Bengkel dan desa Pangkung Tibah yang mempunyai luas baku seluas 345 hektar. Subak Bengkel memiliki anggota 438 orang yang terbagi dalam empat tempek.

\subsection{Fasilitas yang dimiliki Subak Bengkel}

Fasilitas yang dimiliki Subak Bengkel yaitu tanah hak milik yang berukuran 400m2, balai subak yang berjumlah 1 unit didapat dari bansos, kios UPS. Sari Mertha/gudang/toilet berjumlah 1 unit didapat dari bansos, gudang gapoktan berjumlah 1 unit didapat dari bansos, lumbung berjumlah 1 unit, sumur berjumlah 1 unit, pelinggih padmasana berjumlah 1 unit, traktor berjumlah 2 unit didapat dari bansos, power tresher berjumlah 3 unit didapat dari bansos dan transplanter berjumlah 1 unit didapat dari bansos.

\section{Hasil dan Pembahasan \\ 4.1 Umur Informan Kunci}

Berdasarkan Ekalikita, (2011), penduduk usia kerja adalah penduduk usia 15 tahun keatas yang secara aktif melakukan kegiatan ekonomi yaitu kegiatan yang menghasilkan keluaran (output) baik berupa barang maupun jasa. Umumnya menggolongkan umur di bawah 15 tahun dan usia di atas 64 tahun merupakan usia yang tidak produktif, sedangkan umur 15-64 tahun merupakan usia yang produktif.

\subsection{Peran Serta}

Peran serta subak atau kelompok tani dalam program penangkaran benih padi PT. Pertani (Persero) sangat dibutuhkan karena semakin banyaknya subak atau kelompok tani yang ikut dalam program penangkaran maka program ini akan semakin sukses. Tiga tempek yang belum ikut dalam program penangkaran benih ini, terindikasi adanya suatu permasalahan baik dari pihak luar (penyosohan beras, tengkulak) maupun dari PT. Pertani (Persero). Sesuai masalah yang telah dijelaskan di atas maka tujuan dalam penelitian ini mengkaji tentang peran serta subak, manfaat mengikuti program penangkaran dan kendala-kendala petani dalam mengikuti program penangkaran benih padi.

\subsubsection{Peran serta ditinjau dari aspek sosial}

Peran serta ditinjau dari aspek sosial menunjukan peran serta petani dalam pelaksanaanya sangat besar dilihat saat rapat anggota Tempek Pagedangan dengan PT. Pertani (Persero) selalu hadir dan aktif memberikan ide, pendapat atau membahas suatu permasalahan yang terjadi di lapangan dengan sesama petani penangkaran benih padi dan staf PT. Pertani (Persero), selain itu petani penangkar dalam hal sosial sangatlah bagus di mana antara sesama petani penangkar membantu atau saling bergotong royong menaikkan gabah kering ke mobil angkutan dan ada juga peran serta dari pihak luar petani penangkar yaitu masyarakat memberikan sumbangan gedung yaitu salah satu gedung kelas SD (sekolah dasar) untuk dijadikan tempat pembelajaran teknologi pertanian dan teknik pembenihan benih padi yang baik oleh Tempek Pagedangan. 


\subsubsection{Peran serta ditinjau dari aspek ekonomi}

Peran serta petani ditinjau dari aspek ekonomi menunjukkan sangat besar dilihat dari pelaksaannya petani ikut berperan serta dalam bentuk aspek ekonomi untuk memajukan program penangkaran benih padi. Petani penangkar dalam hal sosial untuk memajukan suatu program penangkaran selalu memberikan sumbangan makanan dan minuman secara sukarela untuk kegiatan memajukan program penangkaran benih padi, selain itu peran serta pemerintah dalam program penangkaran benih padi sangat besar dilihat dari memberikan sumbangan saprotan untuk Subak Bengkel dan sumbangan berupa uang untuk memajukan program penangkaran benih padi dan Subak Bengkel.

\subsubsection{Peran serta ditinjau dari aspek teknis}

Peran serta petani ditinjau dari aspek teknis sudah sangat baik dalam pelaksaan mengikuti teknik pembenihan benih padi arahan pengawas PT. Pertani (Persero), setelah melakukan eksperimen dan pembelajaran keluar kota Petani penangkar menemukan teknik pembenihan benih padi yang baik dengan kualitas yang bagus dan hasil yang banyak dari teknik pembenihan benih padi dari PT. Pertani (Persero).

\subsection{Manfaat Program Penangkaran Benih Padi}

Manfaat merupakan suatu hal yang dirasa menguntungkan. Manfaat program penangkaran benih ditinjau dari aspek sosial, aspek ekonomi dan aspek teknis.

\subsubsection{Manfaat program penangkaran ditinjau dari aspek sosial}

Manfaat program penangkaran ditinjau dari aspek sosial yakni terjalinnya relasi yang baik dengan pihak luar petani penangkar benih maupun pihak yang ada didalam petani penangkar benih, bisa dilihat pada pendapat informan kunci diatas terjalinnya hubungan atau relasi yang baik dengan perusahaan atau KUD yang ada disekitar Kecamatan Kediri

\subsubsection{Manfaat program penangkaran ditinjau dari aspek ekonomi}

Manfaat ditinjau dari aspek ekonomi yaitu dari segi harga jual, harga jual gabah yang dibeli oleh PT. Pertani (Persero) lebih besar dari harga dipasaran yaitu sebesar Rp. 200,00 /Kg dari harga jual yang dibeli oleh PT. Pertani (Persero) dapat meningkatkan perekonomian petani penangkar benih padi di Tempek Pagedangan. Dengan didukung dengan teknik pembenihan benih padi dari Kelian Tempek Pagedangan hal ini dapat menghasilkan gabah benih padi yang lebih banyak dengan biaya pemeliharaan benih padi yang lebih sedikit dari biaya pemeliharaan padi konsumsi biasa.

\subsubsection{Manfaat program penangkaran ditinjau dari aspek teknis}

Manfaat ditinjau dari aspek teknis yaitu dari segi ilmu pengetahuan petani penangkar mendapatkan pembelajaran tentang apa itu pertanian modern bagaimana cara menanam benih padi dengan kualitas benih yang bagus dan menghasilkan suatu benih padi yang banyak, disamping itu petani juga bisa mengaplikasikan alat pengukur $\mathrm{pH}$ tanah agar petani bisa mengetahui seberapa tinggi kadar asam yang ada didalam tanah, mengetahui berapa jarak tanam yang cocok untuk calon benih padi pada saat musim kemarau dan musim hujan dan juga meminimalisir biaya untuk pemeliharaan calon 
benih padi karena jarak tanam yang lebar sehingga petani bisa langsung membersihkan gulma disekitar benih padi dan tidak membeli obat untuk memusnahkan gulma tersebut.

\subsection{Kendala-Kendala dalam Mengikuti Program Penangkaran Benih Padi}

Kendala subak dalam program penangkaran benih padi ditinjau dari aspek sosial, aspek ekonomi dan aspek teknis.

\subsubsection{Kendala-kendala ditinjau dari aspek sosial}

Kendala ditinjau dari aspek sosial yaitu dalam pelaksanaannya banyak kendala yang dihadapi petani untuk ikut dalam program penangkaran benih padi seperti sulitnya dalam mengubah persepsi petani yang sudah tua untuk ikut dalam program penangkaran, selain itu dalam aspek sosial yakni banyak persyaratan yang diberikan PT. Pertani (Persero) tidak bisa disanggupi oleh petani calon penangkar benih padi, dan juga adanya ancaman langsung dari penyosohan beras yang ada disekitar Desa Bengkel terhadap petani penangkar.

\subsubsection{Kendala-kendala ditinjau dari aspek ekonomi}

Kendala ditinjau dari aspek ekonomi yaitu dalam pelaksanaanya bahwa kendalakendala yang dialami petani calon penangkar dan petani penangkar dalam mengikuti program penangkaran dilihat dari aspek ekonomi yaitu permodalan, modal yang dimaksud adalah modal berupa tanah maupun modal yang berupa uang.

\subsubsection{Kendala-kendala ditinjau dari aspek teknis}

Kendala-kendala ditinjau dari aspek teknis yaitu dalam pelaksanaannya bahwa kendala-kendala yang dialami petani calon penangkar dengan kendala-kendala yang dialami petani penangkar dalam mengikuti program penangkaran benih padi dilihat dari aspek teknis yaitu susahnya menerapkan teknik pembenihan benih padi dari PT. Pertani (Persero) karena kebanyakan petani sudah tua dan malas sehingga para petani tidak ingin ikut dalam program penangkaran benih padi dan susah mencari benih dasar untuk dijadikan benih sebar dan benih konsumsi karena kurangnya relasi atau kenalan dari tempek tersebut.

\section{Simpulan dan Saran}

\subsection{Simpulan}

Berdasarkan hasil penelitian dan pembahasan yang telah diuraikan, maka hasil penelitian ini dapat disimpulkan sebagai berikut.

1. Peran serta Subak Bengkel dalam program penangkaran benih padi PT. Pertani (Persero) ditinjau dari tiga aspek yakni aspek sosial, aspek ekonomi, dan aspek teknis. Peran serta ditinjau dari aspek sosial sangat besar dilihat dari antusias anggota yang besar dalam mengikuti dan memberikan suatu ide, pendapat dan pemikiran. Peran serta petani dilihat dari aspek ekonomi sangat besar dapat dilihat dari petani membayar iuran perbulan, adanya sumbangan dana secara suka rela dari petani penangkar dan sumbangan dari pemerintah. Peran serta ditinjau dari aspek teknis dilihat peran serta petani sangat bagus dimulai dari mengikuti arahan tehnik pembenihan benih padi dari PT. Pertani (Persero). 
2. Manfaat program penangkaran benih ditinjau dari tiga aspek yakni aspek sosial, aspek ekonomi dan aspek teknis. Manfaat program penangkaran benih ditinjau dari aspek sosial yaitu terjalinnya hubungan yang baik antara sesama petani penangkar, terbentuknya relasi yang baik dengan PT. Pertani (Persero), dan KUD Denbantas. Manfaat program penangkaran ditinjau dari aspek ekonomi yaitu harga gabah yang dibeli oleh PT. Pertani (Persero) lebih tinggi Rp. 200,00 dari harga dipasaran. Manfaat program penangkaran ditinjau dari aspek teknis yaitu petani penangkar mendapatkan ilmu tentang tehnik pembenihan benih padi yang baik dan berkualitas.

3. Kendala-kendala dalam program penangkaran benih padi ditinjau dari tiga aspek yakni aspek sosial, aspek ekonomi dan aspek teknis. Adapun kendala petani dalam program penangkaran ditinjau dari aspek sosial yaitu ketatnya persyaratan dari PT. Pertani (Persero), sulitnya mengubah persepsi petani yang sudah tua dan adanya ancaman dan gesekan dari pihak penyosohan beras yang ada di Desa Bengkel dan sudah berlangsung selama 17 tahun. Kendala yang dialami oleh petani ditinjau dari aspek ekonomi yaitu kekurangan modal, modal berupa uang dan modal berupa tanah. Kendala petani mengikuti program penangkaran benih padi dintinjau dari aspek teknis yaitu masih banyaknya petani yang malas dalam menerapkan teknik pembenihan benih padi dan masih susahnya mendapatkan benih dasar untuk dijadikan benih sebar.

\subsection{Saran}

Berdasarkan hasil penelitian dapat disarankan sebagai berikut.

1. Bagi kelompok tani atau subak yang ingin ikut program penangkaran agar lebih dahulu memepelajari tehnik budidaya benih padi sebelum mengikuti program penangkaran ini.

2. Bagi PT. Pertani (Persero) agar lebih sering mensosialisasikan program penangkaran benih padi ini supaya petani calon penangkar mengetahui secara jelas syarat, ketentuan dan manfaat jika mengikuti program penangkaran benih padi ini.

3. Bagi ketiga tempek yang belum ikut program penangkaran supaya mengikuti program penangkaran ini karena menguntungkan petani dari segi manfaat.

4. Bagi Tempek Pagedangan supaya membicarakan masalah yang dihadapi secara langsung dengan pemilik pabrik penyosohan beras agar konflik yang terjadi dapat terselesaikan dan dapat menguntungkan kedua belah pihak baik dari pabrik penyosohan beras dan Tempek Pagedangan.

\section{Ucapan Terimakasih}

Terimakasih kepada semua pihak yang telah memberikan berupa data, buah pikiran, kebendaan dan lain-lainnya sehingga e-jurnal ini dapat diselesaikan dengan baik semoga hal didalamnya bermanfaat adanya.

\section{Daftar Pustaka}

Ariani, M. 2007. Penguatan Ketahanan Pangan Daerah Untuk Mendukung Ketahanan Pangan Nasional. Pusat Penelitian dan Pengembangan Sosial Ekonomi Pertanian. Bogor. 
Agusta, Ivanovich. 2012. Teknik Pengumpulan dan Analisis Data Kualitatif http://www.academia.edu/download/34265413/ivan-pengumpulan-analisis-datakualitatif.pdf diakses 10 Maret 2017

Antara , M. 2006. Bahan Ajar Mata Kuliah Metode Penelitian Agribisnis. Program Studi Magister, Program Pasca Sarjana Universitas Udayana. Denpasar.

Ekalikita. 2011. Sedahan Agung Yeh Ho I Kecamatan Kerambitan, Kabupaten Daerah tingkat II Tabanan.

Hanafi, M. 1998. Analisis Pemasaran di PT.Sang Hyang Seri Cabang Khusus Jawa Barat untuk Produk Benih Padi Bersertifikat. Fakultas Pertanian. Institut Pertanian Bogor. Bogor.

Ibrahim, 2015. Metode Penelitian Kualitatif. Bandung. Alfabeta

Suryana, A. 2003. Kapita Selekta Evolusi Pemikiran Kebijakan Ketahanan Pangan. BPFE-Yogyakarta.

Sugiyono. 2009. Metode Penelitian Bisnis (Pendekatan Kuantitatif, Kualitatif, dan $R \& D)$. Bandung. Alfabeta.

Sutopo. 2006. Metodologi Penelitian Kualitatif. Surakarta. UNS

Wahyuni. 2014. In-Depth Interview (Wawancara Mendalam) dalam http://qmc.binus.ac.id/2014/10/28/in-depth-interview-wawancara-mendalam/ diakses 3 Juni 2017 